\title{
Рецепция прозаических произведений А.Б. Мариенгофа в русскоязычной журналистике в 1926-1929-х гг.
}

\author{
Муртазина Д.Р. \\ Российский государственный гуманитарный университет, \\ Россия, 125993, г. Москва, Миусская пл., 6. \\ E-mail: murtazina.dasha@gmail.com
}

\begin{abstract}
Аннотация. Для изучения истории журналистики, особенно советского периода, важную роль играет анализ политического контекста. Несмотря на многочисленные исследования имажинизма, исследования политических причин неприятия прозы А.Б. Мариенгофа отсутствуют. Целью данного исследования является анализ рецепции в русскоязычной журналистике в 1926-1929 гг. произведений Мариенгофа «Воспоминания о Есенине», «Роман без вранья», «Циники». Автор рассматривает влияние политических событий в СССР на рецепцию произведений Мариенгофа и его литературную репутацию. Сделаны выводы, что реакция на «Роман без вранья», во многом продиктованная статьей Н.И. Бухарина «Злые заметки», породила дискуссию о том, каким должен быть советский писатель; публикация романа «Циники» в зарубежном издательстве выступила скорее формальной причиной для травли Мариенгофа, реальные же причины критики романа были в неоднозначности посыла самого произведения и сложившемся образе его автора как отрицательного персонажа в мире советской литературы.
\end{abstract}

Ключевые слова: С.А. Есенин, советская журналистика, журналистика русского зарубежья, «Роман без вранья», журнал «Огонёк», Н.И. Бухарин, Л.Д. Троцкий, роман «Циники».

Для цитирования: Муртазина Д.Р. 2020. Рецепция прозаических произведений А.Б. Мариенгофа в русскоязычной журналистике в 1926-1929-х гг. Вопросы журналистики, педагогики, языкознания, 39 (3): 356-366. DOI 10.18413/2712-7451-2020-39-3-356-366

\section{Reception of Marienhof's prose in soviet journalism at 1926-1929-ies}

\author{
Darya R. Murtazina \\ Russian State University for the Humanities, \\ 6 Miusskaya sq., Moscow, 125993, Russia. \\ E-mail: murtazina.dasha@gmail.com
}

\begin{abstract}
Analysis of the political context plays an important role in studying the history of journalism, especially in the Soviet period. Despite numerous studies of imagism, there are no studies of the political reasons for rejection of A. B. Marienhoff's prose. The purpose of this research is to analyze the reception in Russian-language journalism in 1926-1929 of Marienhoff's works "Memories of Yesenin", "novel without lies", "Cynics". The author examines the influence of political events in the USSR on the reception of Marienhoff's works and his literary reputation. It is concluded that the reaction to the "novel without lies", largely dictated by the article N.And. Bukharin "Evil notes" generated discussion about what should be a Soviet writer; the publication of the novel "the Cynics" in the foreign publisher made rather formal reason for persecution Mariengof, the real reason critics of the novel was the ambiguity of the message of the work itself and the prevailing image of the author as a negative character in the world of Soviet literature.
\end{abstract}


Keywords: S.A. Esenin, soviet journalism, journalism of Russian emigrants, A novel without lies, Ogoniok magazine, N.I. Bukharin, L.D. Trotsky, novel Cynics.

For citation: Murtazina D.R. 2020. Reception of Marienhof's prose in soviet journalism at 1926-1929ies. Issues in Journalism, Education, Linguistics, 39 (3): 356-366 (in Russian). DOI 10.18413/27127451-2020-39-3-356-366

\section{Введение}

Один из крупнейших литературных скандалов 1920-х гг. возник вокруг публикации воспоминаний А.Б. Мариенгофа - «Романа без вранья». В них Мариенгоф пишет о событиях, относившихся главным образом к периоду его участия в литературном объединении имажинистов, лидером которого считался С.А. Есенин. Сам Мариенгоф, как известно, был ближайшим другом. Есенина, ставшего главным героем мемуарного романа. Автор попытался воссоздать образ друга вне каких-либо политических или же литературных пропагандистских установок. Однако этот тезис не был принят многими современниками. $\mathrm{C}$ автором ожесточенно полемизировали литературные критики, литературоведы и писатели. Этот скандал сильно повлиял на жизнь и карьеру Мариенгофа, а также на восприятие журналистами, литературоведами и широкой аудиторией других его произведений.

До недавнего времени жизнь и творчество писателя А.Б. Мариенгофа были мало изучены: книга «Анатолий Мариенгоф, первый денди Страны Советов» исследователя А.В. Демидова [2019], вышедшая в 2018 г., стала первой полноценной биографией писателя, подробно описывающей все этапы его жизни. Тем не менее, журналисты, литературные критики и литературоведы до сих пор часто воспринимают Мариегофа исключительно как друга поэта С.А. Есенина.

Ввиду недостаточной изученности творчества писателя, до сих пор никто из исследователей комплексно не анализировал рецепцию прозаических произведений Мариенгофа в журналистских материалах в 1926-1929 гг. Именно в этот период проза Мариенгофа не только регулярно публиковалась, но и становилась предметом дискуссий.

Анализ рецепции прозы Мариенгофа предполагает понимание принципов взаимодействия литературы с властью в 1920-е годы. О политическом контексте темы исследования пишет в своих работах Д.М. Фельдман: он изучает взаимотношение литературных группировок начала XX века (в том числе и имажинистов) с властью [Фельдман, 2017], а также влияние статьи Н.И. Бухарина «Злые заметки» на восприятие в журналистике творческого наследия С.А. Есенина и имажинистов [Фельдман, 2011].

Б.В. Аверин, написавший предисловие к первому вышедшему во время перестройки изданию прозы Мариенгофа, упоминал, что негативная реакция на «Роман без вранья» была связана с тем, что Мариенгоф разрушил образ Есенина как поэта деревни [Аверин, 2008].

Непосредственно изучением творчества Мариенгофа занимались такие исследователи, как Т.А. Тернова [2011], В.А. Сухов [2012], О.В. Демидов [2012], Г.Г. Исаев [2015], из иностранных - Г. Маквей [2011] и Т. Хуттунен [Хуттунен, 2018].

Мариенгофа часто упоминают исследователи творчества Есенина: например, Савченко [2019] не изучает творчество Мариенгофа, но и не демонизируют его образ, как это иногда бывает в публицистических текстах о Есенине. Никто из исследователей не изучал политический контекст скандала вокруг Мариенгофа в 1920-е гг. и рецепции его прозы в советской периодике.

В данной работе будет проанализирована рецепция прозы Мариенгофа в советской периодической печати и её исторический контекст. Речь пойдет о рецепции следующих произведений: «Воспоминания о Есенине» (1926) издательства «Огонек»; воспоминания «Роман без вранья» $(1927,1928,1929)$; роман «Циники» (1928), вышедший в берлинском издательстве «Петрополис». Помимо этих произведений, при жизни Мариенгофа вышло 
ещё два прозаических произведения («Бритый человек» и «Екатерина»), однако в советской журналистике они почти не были замечены, поэтому в данном исследовании упомянуты не будут.

\section{Объекты и методы исследования}

Объект исследования - публикации, отражающие восприятие вышеуказанных произведений в русскоязычной журналистике. Автор анализирует русскоязычные материалы как периодических изданий, выходивших в СССР («Огонёк», «Литературная газета», «Октябрь», «На литературном посту», «Красная новь», «Красная вечерняя газета», «Гудок», «Работа и искусство»), так и эмигрантских газет и журналов, издававшихся в Европе («Руль», «Иллюстрированная Россия», «Возрождение», «Воля России»).

Исследование выполнено с применением компаративного метода: автор описывает и анализирует содержание материалов, выявляя общее и различное между ними. Также анализируется исторический и политический контекст, что необходимо для анализа материалов советской журналистики, являвшейся инструментом пропаганды. В конце автор подводит итоги, резюмируя причины, существенно повлиявшие на рецепцию прозы Мариенгофа в 1920-х гг.

\section{Политический контекст рецепции прозы Мариенгофа}

При анализе рецепции двух мемуарных произведений Мариенгофа («Воспоминания о Есенине» и «Роман без вранья») особенно важно знание исторического контекста.

Писателям после 1917 г. для выживания необходимо было сотрудничать с правящей партией, по возможности не вступая в нее. Член партии - боевая единица, поэтому интеллигенция хотела сотрудничать с партией иначе. После 1917-х гг. формируется движение писателей-попутчиков: Л.Д. Троцкий ввел этот термин, и поначалу он не имел негативной окраски.

Имажинисты, среди которых Есенин, Мариенгоф и другие, стали «попутчиками», выражающими интересы правящей партии. Троцкий, очевидно, симпатизировал Есенину и считался его «покровителем». В 1919-1925 гг. имажинизм развивался очень успешно: устраивались творческие вечера, имевшие большую популярность, выпускалось множество авторских и коллективных сборников; были созданы издательства и литературное кафе.

Уже в 1922 г. Троцкий начал терять свои позиции на политической арене. Ленин пережил инсульт, встал вопрос о наследнике вождя. И.В. Сталин занял должность генерального секретаря ЦК РКП (б), которая не интересовала Троцкого - он считал ее «технической» и не очень значимой. После смерти Ленина в 1923 г. Началась активная борьба за власть, Троцкий был вынужден противостоять сформировавшейся тройке: Сталин Каменев - Зиновьев. Есенин понимал, что нужно искать нового покровителя, и на эту роль отлично подходил Бухарин - на тот момент он «не только ценнейший и крупнейший теоретик партии, он также законно считается любимцем всей партии» [Ленин, 1988, с. 440]. Бухарин - борец с «троцкистской» оппозицией; после смерти Ленина - один из самых влиятельных руководителей партии и государства. Бухарину также было выгодно покровительствовать Есенину: его стихи были близки простому народу.

К Мариенгофу Бухарин давно относился хорошо: именно благодаря Бухарину Мариенгоф получил должность ответственного литературного секретаря издательства ВЦИК, когда только приехал в Москву. Этот эпизод описан в «Романе без вранья» [Мариенгоф, 1927].

Есенин умер в декабре 1925 г., и до конца 1926 г. его стихи регулярно печатались в крупных литературных журналах страны: «Красной нови», «Октябре» и др. В 1927 г. вышел «Роман без вранья». В нём писатель рассказывал о роскошной жизни имажинистов в период, когда в стране царил голод. 
12 февраля 1927 года отношение власти к Есенину официально изменилось. В «Октябре» вышла статья «Злые заметки» Н.И. Бухарина [1927], ясно выражающая взгляды руководства партии: «есенинщина» признавалась явлением отрицательным. «Это отвратительная, напудренная и нагло раскрашенная российская матерщина, обильно смоченная пьяными слезами и оттого еще более гнусная», - пишет Бухарин [1927, с. 133]. Это был один из методов борьбы с Троцким: Есенин ассоциировался именно с ним. Вероятно, Бухарин смог официально воспрепятствовать пропаганде «есенинщины» только после исключения Троцкого из Политбюро ЦК. Статья Бухарина вышла почти сразу после «Романа без вранья»: ему было необходимо отделить себя от своего образа, описанного в воспоминаниях Марниангофа. Описанный в мемуарах Есенин власти был не нужен.

Как реагируют на «Роман без вранья» в советских журналах и газетах?

Обратим внимание на то, что упоминания о «Романе без вранья» отсутствуют в «Красной нови», «Новом мире», «Печати и революции», «Звезде», «Октябре» в годы издания книги, то есть в 1927-1929 гг. Для них, как для «серьезных» журналов, выразителей официальной позиции власти, мемуары о Есенине и его образе жизни просто не существовали. Умолчание в пропаганде - это один из способов формирования необходимой картины мира. Однако книга была очень популярна, её обсуждали и переиздавали дважды.

Интересно посмотреть, как сменил свое мнение о воспоминаниях Мариенгофа журнал «Огонёк», находившийся в 1926-1929 гг. под крылом у Бухарина. Именно в серии «Библиотека "Огонька"» выходит предшественник «Романа без вранья», первая версия мемуаров Мариенгофа - «Воспоминания о Есенине» [Мариенгоф, 1926]. Это издание не было эпатажным. В «Огоньке» выходу книги не придали особого внимания, в анонсе писали, что книга содержит «интересные факты» о поэте.

А вот уже в 1929 г. в «Огоньке» выходит критическая статья о «Романе без вранья» [Самсонов, 1929]. Самсонов обвиняет Мариенгофа в том, что книга имеет «немало умолчаний», «не только не способна вызвать творческих чувств, но от начала до конца является антиобщественным произведением, идеализирующим социально вредные наклонности богемы», «способна породить в читателе лишь анархические и дезорганизаторские склонности» [Самсонов, 1929, с. 6]. В общем - порицание Мариенгофа и книги, полностью созвучное «Злым заметкам» Бухарина. Самсонов прибавляет, что всё ж таки «Роман без вранья» можно было бы назвать мемуарами русской литературной богемы, но отмечает, что Мариенгофу не хватает правдивости в изложении событий. То есть, по мнению автоpa, не всё в книге - правда. Автор статьи также обвиняет Мариенгофа в неверном понимании и истолковании событий, происходивших в стране.

Тональность выходивших после статьи Бухарина рецензий на «Роман без вранья» была примерно одинаковая: авторы повторяли мысли политического деятеля. Некоторые отзывы приобрели яркую художественную окраску.

В этом смысле особенно примечательна статья талантливых пародистов А.Г. Архангельского и М.Я. Пустынина [1927] со звучным названием «Вранье без романа», вышедшая в журнале «На литературном посту». Примечательно то, что этот журнал являлся органом РАПП (Российской ассоциации пролетарских писателей), который противостоял движению попутчиков и, соответственно, изначально (т.е. до статьи Бухарина) не отзывался хвалебно о Есенине и его товарищах.

Каждый конкретный абзац статьи «Вранья без романа» отсылает нас к какой-либо детали из мемуаров Мариенгофа или из газетных статей в целом: очевидно, что современникам было понятно, что имеют в виду авторы. Таким образом, авторы статьи мастерски превратили заурядную пропагандистскую травлю в произведение, в котором отражены самые обсуждаемые события эпохи. Разберем пару примеров.

Архангельский и Пустынин посмеиваются над обилием в «Романе без вранья» описаний еды, которую Мариенгоф с Есениным поглощали на фоне повального голода в стране: «Я окунулся в события с головой. В качестве инспектора конотопского унаробраза, 
куда я переехал из голодного Петрограда, я повел бешеную работу, по 24 часа в сутки, бегая по всем учреждениям за получением пайков» [Архангельский, Пустынин, 1927, с. 125].

Упоминается во «Вранье без романа» некий Сережа Говорков: «Сережа Говорков, этот светлый юноша, погибший впоследствии во время гражданской войны (в "Стойле пегаса" в Москве ему проломили бутылкой голову), достал бутылку водки, и под буханье пушек, татаканье пулеметов и частые ружейные выстрелы мы распили её во славу русской литературы» [Архангельский, Пустынин, 1927, с. 126]. Это, конечно, пародия на Есенина и его образ жизни: в плохом влиянии на поэта, в том числе и спаивании, сразу после смерти Есенина начали обвинять имажинистов [Лавренев, 1925].

В сатирическом ключе о «Романе без вранья» писала газета «Гудок». В статье «Голый писатель» Б.С. Шихман назвал «Роман без вранья» «записками лакея о мелочах “барского" быта» [Шихман, 1927]. Автор отметил, что на книгу он обращает внимание в первую очередь потому, что она представляет собой соблазн для молодых читателей. Появление статьи он связал с заботой о молодом поколении, на самом же деле «вкладывая» этому поколению правильное восприятие книги.

Все привлекающие элементы книги (ироничный тон и самоуверенный стиль, панибратство со знаменитостями и образованность, политические убеждения - уважение к советской власти) Шихман назвал «наивной маскировкой», которая необходима писателю, чтобы «провести контрабандным путем несколько десятков скандальных историй и фактов из жизни живых людей» [Шихман, 1927, с. 4]. Цель Мариенгофа, по мнению автора статьи, - поделиться сплетнями из жизни известных людей. В каком-то смысле это и есть определение жанра мемуаров - об этом Шихман как-то забыл. Очевидно, что он осуждал «как», а не «что» написано в книге.

Отзывов о «Романе без вранья», которые написаны в одной тональности со «Злыми заметками» Бухарина, вышло довольно много в 1927-1929 гг. и анализировать их все не имеет смысла. Важно, что единая направленность этих отзывов убеждает в их политической ангажированности. Откровенность Мариенгофа в мемуарах оказалась невыгодной для части политической элиты в условиях борьбы за власть.

\section{Влияние дружбы с Есенином на рецепцию прозы Мариененгофа}

Обратимся ко второму аспекту рецепции прозы Мариенгофа. На момент выхода «Романа без вранья» в литературной критике существовал определенный образ Есенина: он воспринимался как поэт деревни, при анализе его стихов чаще всего внимание уделялось образам деревенской Руси, пейзажам. Образ Есенина из «Романа без вранья» расходился с уже существующим. Когда Есенин «связался» с имажинизмом, многие литературные критики восприняли это негативно, имажинистов обвиняли в том, что Есенина сбили с верного пути. Отчасти это происходило по политическим причинам: «народные» стихи Есенина были нужны для пропагандистских целей.

Ещё в 1924 г. Воронский А.К. в статье «Литературные силуэты. Сергей Есенин» написал, что поэт ушел с верного направления, создав с Мариенгофом и Шершеневичем имажинизм: «Он терял себя и обращался со своим даром, как лихой расточитель. Непосредственность, крепость своего деревенского поэтического таланта он отдавал на служение интересам литературных стойл и групп» [Воронский, 1924, с. 272].

Мариенгоф в «Романе без вранья» написал, что Есенин «бесконечно любил и город, и городскую жизнь, и городскую панель, исшарканную и заплеванную. За четыре года, которые мы прожили вместе, всего один раз он выбрался в свое Константиново. Собирался прожить там недельки полторы, а прискакал через три дня обратно, отплевываясь, отбрыкиваясь и рассказывая, смеясь, как на другой же день поутру не знал, куда там себя девать от зеленой тоски» [Мариенгоф, 1927]. 
В этой связи удивителен сам факт выхода книги «Роман без вранья» в 1927 г. Например, воспоминания В.П. Катаева «Алмазный мой венец», где присутствует подобное развенчание образа Есенина как любителя деревни, вышли только в 1978 г. «Роман без вранья» еще и переиздавался дважды: в 1928 и 1929 г. Это говорит о популярности книги: в период НЭПа, который длился до 1929 г., когда окупаемость и прибыльность частных предприятий (в том числе и издательств) была крайне важна. «Прибой» издал воспоминания Мариенгофа из-за коммерческой выгоды.

После 1929 г. цензура усилилась. До выхода в 1927 г. «Злых заметок» Бухарина статьи в периодических изданиях были преимущественно направлены против имажинистов, негативно повлиявших на Есенина: сам он оставался «положительным» персонажем [Лавренев, 1925].

Борьба против есенинщины и окружавшей его богемы привела к изданию статей против этих явлений отдельной книгой - «О писательской этике, литературном хулиганстве и богеме». Вступление к сборнику написал первый нарком просвещения А.В. Луначарский, что приравнивает сказанное в издании к официальной позиции власти: «Время оценки и переоценки не общих устоев, а именно деталей и конкретных проявлений текущей жизни пришло» [Луначарский, 1927, с. 3]. Первая статья - «Злые заметки» Бухарина, также в сборник вошли тексты его сподвижников: Л.С. Сосновского, Г. Лелевича, М.С. Лучанского и др. Авторы статей будто бы абстрактно пишут о писательстве, об аспектах его жизни, условиях работы, но название сборника включает сразу два понятия, которые неизменно относили в те годы к Есенину и имажинистам: это литературное хулиганство и богема. Этот сборник - понятный для писателей посыл о том, каким не должен быть советский писатель.

Для того, чтобы утвердиться в политизированности рецепции прозы Мариенгофа в советской журналистике, достаточно взглянуть на отзывы в эмигрантских изданиях.

В 1927 г. литературный критик Ю.И. Айхенвальд [1927] написал для берлинской газеты «Руль» объемную рецензию на «Роман без вранья». Первое, что бросается в глаза в тексте нету штампов и тональности советских отзывов, что логично. Так как Айхенвальд традиционно выступал с критикой советской власти, то и в «Романе без вранья» он обратил внимание на то, что герои «распущены, разнузданы и начали позволять себе все после октября, когда стало всё позволено». Мы видим, что Айхенвальду не нравится привилегированное положение имажинистов, которых «спонсировала» власть. Автор презрительно относился к советской власти и поэтому отрицательно отзывался о ее пособниках. Айхенвальд отмечал, что книга «очень интересна, как материал, характеризующий преломление революции в определенной литературной среде».

Айхенвальду не нравилось, что для образа Есенина Мариенгоф не пожалел самых непривлекательных красок: «то серьезное, что было в этом поэте, духовный смысл его даровитой личности, под пером его биографа отходит куда-то на далекий план, а на первый выдвигается пошлость и низменность, и самая прозаическая расчетливость». К «живому» и нестандартному образу поэта оппозиционно настроенный Айхенвальд не был готов.

В.Ф. Ходасевич в статье «Цыганская власть» написал, что написанному Мариенгофом можно доверять, «в особенности потому, что, изображая имажинистскобольшевистскую Москву очень неприглядной, он сам этой неприглядности не чувствует» [Ходасевич, 1927]. В отличие от многих рецензентов, Ходасевич подметил, что в центре воспоминаний Мариенгофа - не Есенин, а «та банда, которой он был окружен, и тот фон, тот общий порядок, при котором банда могла «жить и работать»» [Ходасевич, 1927, с. 4].

Заметил Ходасевич и причину недовольства многих «Романом без вранья» в частности и имажинистами в целом. Ходасевич непредвзято написал о том, о чем не могли писать советские газеты и журналы, но что было понятно каждому, жившему в то время: «В годы общих мучений, в пору военного коммунизма, вся эта публика жила, по сравне- 
нию с прочими, припеваючи, потому что сумела перенести на себя часть того привилегированного положения, которым пользовались большевики».

С Ходасевичем полемизировал И.А. Бунин [1927] в статье «Самородки», он был согласен с тезисами коллеги, однако был не согласен в одном: «будто в "трагедии" и во всех качествах Есенина виновата "цыганская власть", как называет Ходасевич власть большевистскую». Бунин соглашался, что имажинисты были полезны как группа, «вносящая сумятицу и безобразие в русскую литературу» [Бунин, 1927, с. 15]. Он полагал, что Есенина погубила не «цыганская власть», а он сам, его образ жизни. Это противоречит советской тональности рецепции на «Роман без вранья».

Адамович в статье «Воспоминания о Есенине» писал, что «Роман без вранья» «едва ли не лучшая книга, чтобы узнать и понять Есенина» [Адамович, 1929]. Автор статьи отмечал, что вранья в книге действительно не заметно, Мариенгоф рисует образ Есенина без прикрас.

В целом для эмигрантской рецепции «Романа без вранья» характерна общая антисоветская направленность, которую очень удачно можно иллюстрировать отрывками из воспоминаний Мариенгофа. Эмигранты, в первую очередь, критиковали не книгу, а устройство советского государства. Также характерно для рецепции и отсутствие сомнений в правдивости воспоминаний.

\section{Роман «Циники»}

Обратимся теперь к рецепции романа «Циники». Он вышел в берлинском издательстве «Петрополис» в 1928 г. Мариенгоф надеялся на публикацию романа в СССР, однако в Берлине он вышел раньше: разрешения на публикацию на родине писатель не получил (и непонятно, насколько велики были шансы). Всё выглядело так, будто он издал за границей запрещенный роман.

В 1929 г. в «Красной газете» вышла статья Д.Н. [1929] «За Пильняком и Замятиным - Мариенгоф». Оказаться в одном ряду с Пильняком и Замятиным - не самое приятное обстоятельство для писательской карьеры: в августе 1929 г. «Литературная газета» начала кампанию против Пильняка и Замятина. Оба писателя печатали свои произведения за границей, в том числе и в издательстве «Петрополис».

В целом реакция газет и журналов на выход романа «Циники» не была такой же разнообразной и продолжительной, как кампания, развернутая против «Романа без вранья». Плохой имидж Мариенгофа в советской журналистике «наложился» на дело Пильняка и Замятина.

Автор статьи в «Красной газете» негативно отозвался о «Циниках», а также отметил, что после разъяснения ситуации с «Циниками» характер творчества Мариенгофа слишком хорошо знаком советской общественности.

Мариенгофу пришлось публично извиниться за публикацию романа за границей и объясниться: «Считаю появление за рубежом произведения, не разрешённого в СССР, недопустимым. Опубликование моего романа, не появившегося у нас, считаю ошибочным поступком» [Мариенгоф, 1929].

Московский отдел Всероссийского союза писателей (предшественник Союза писателей СССР), в свою очередь, вынес вердикт: «Принимая к сведению письмо и. Мариенгофа, правление вместе с тем указывает, что тенденциозный подбор фактов в романе “Циники", искажающий эпоху военного коммунизма и первого периода нэпа, делает книгу объективно вредной и неприемлемой для советской общественности. Автор ведёт роман от лица людей, враждебных советской власти, причем текст романа не даёт материала, отделяющего точку зрения автора от точки зрения действующих лиц. Это обстоятельство ставит перед Мариенгофом необходимость критически отнестись к своему произведению, 
так как роман «Циники» стоит в прямом противоречии с задачами советского писателя, как их определяет ВССП» [Постановление правления ...; 1929].

В эмигрантской периодике снова можно проследить реакцию на эту ситуацию со стороны: «Буря, поднятая литературными "охранителями" по поводу "вредных уклонов" советских писателей, всё ещё не унимается в Москве и Петрограде» [Воля России, 1929].

Автор статьи (не назвавший себя) называет письмо Мариенгофа покаянием и считает, что это «покаянное письмо» Мариенгофа должно было бы удовлетворить «блюстителей политической благонадежности у писателей». Но правление Московского отдела Всероссийского союза советских писателей сочло иначе: книга признана вредной и неприемлемой.

Интересен отзыв на роман «Циники», который вышел в газете «Работа и искусство». Автор А. Кут рассказал «о провинциальной поездке Рюрика Ивнева и Анатолия Мариенгофа и о тех мыслях, какие она навевает» [Кут, 1929].

Сначала автор сожалеет о том, что в провинциальные города приезжает мало советских писателей, поэтов и критиков. Но бывает, что приезжает какая-нибудь «знаменитость» (слово в кавычках приобретает противоположный смысл). Так автор готовит читателя к рассказу о поездке Мариенгофа и Ивнева в Вятку. Свой рассказ автор заметки сопровождает цитатами из газеты «Вятская правда». Негативная оценка визиту писателей была дана в региональной газете, и автор из «Работы и искусства» повторил ее в издании союзного уровня. Автор статьи осуждал Мариенгофа за положительную оценку издательства «Петрополис», продолжая цитировать региональное издание. «Вятская правда» назвала этот эпизод «вылазкой классового врага»: «Как иначе можно расценить те слова, которые были сказаны о белогвардейском издательстве "Петрополис" которое Мариенгоф называл чуть ли не филиалом ГИЗ'а? Как можно было иначе квалифицировать, правда, затушеванное сообщение о том, что "Литературная Газета", начав кампанию против продавшихся "Петрополису" писателей [среди которых был и сам Мариенгоф], сделала политическую ошибку, и заявила о том, что "еще неизвестно, чем вся эта история кончится"» [Кут, 1929, стр. 3].

Речь Мариенгофа нельзя назвать осторожной: очевидно, на встрече в Вятке он говорил то, что думал, и не мог предположить, что слова эти будут использованы против него. «Вятская правда» отметила, что рабочие и преподаватели вузов сумели дать достойный отпор писателю, когда он «пытался “перекрасить пильняковщину в красный цвет”». В итоге, Мариенгоф признал, что «он органически не связан с рабочим классом и не знает его». Это возвращает нас к клейму богемы, которое «прилипло» к Мариенгофу после издания «Романа без вранья».

Автор заметки в газете «Работа и искусство» отметил, что нас [советских людей] не интересуют взгляды Мариенгофа, разве что они могут заинтересовать Всероссийский союз советских писателей, «который уже дважды указал Мариенгофу, что его мировоззрение мало имеет общего с теми положениями, которые обязательны для всякого советского писателя» [Кут, 1929]. Материал указывает место Мариенгофу, дисквалифицируя его как советского писателя.

К кампании против «Циников» присоединились голоса рапповцев: «Антисоветские произведения Пильняка, Замятина и Мариенгофа не случайность <..> они показывают, какие процессы происходят в среде попутничества» [Панов, 1929, стр. 86].

Эмигрантская русскоязычная журналистика не присоединилась к советской травле, однако встретила роман «Циники» неоднозначно. В журнале «Воля России» в рецензии на «Циников» Н.Ф. Мельникова-Папоушкова написала, что в романе за вымышленными масками прячутся реальные люди, и отнеслась к этому негативно: «Не знаю, почувствовал ли А. Мариенгоф всю неловкость выворачивания чужой жизни под видом литературного произведения, проснулся ли в нем стыд и зашевелился страх перед возмездием, или наконец он просто решил заинтересовать читателя прозрачными масками, сквозь которые про- 
свечивает действительность» [Мельникова-Папоушкова, 1929, стр. 135]. По ее мнению, циником выглядит автор романа, а не герои. Мельникова-Папоушкова считает, что в русской литературе, не считая шалостей вроде «Гаврилиады», до конца XIX в. не было «ни цинизма, ни даже грязи Поль-де-Коковского жанра». Основателем жанра автор считает Арцыбашева, но он, по ее мнению, «все свёл лишь к половым излишествам». «Примешивание же чисто органической грязи в виде пота, мыльной воды, вычесанных волос ввел И. Эренбург». Автор рецензии считает, что Мариенгоф его «перещеголял, дойдя до вазелина, клизм и пр.». По сути, автора статьи возмутило то самое смешение высокого и низкого, характерное для имажинизма, и уже использованное в «Романе без вранья».

Айхенвальд считал, что Мариенгоф эпатировал читателя нарочно (что для писателя было очень характерно): «Возмущаться этим романом значило бы доставить его советскому автору большое удовольствие: ведь он, очевидно, и хотел удивить, возмутить epater le bourgeois или тех, кто ещё не отделался от буржуазных предрассудков стыда» [Айхенвальд, 1928]. Айхенвальд был убежден, что роман не найдет своего читателя.

Таким образом, в советской периодике роману «Циники» моментально и очень громко была дана отрицательная оценка в связи с кампанией против Пильняка и Замятина. Однако по другим материалам печати можно увидеть, что выход романа в зарубежном издательстве не был основным поводом для травли.

\section{Заключение}

Значительное влияние на рецепцию прозы Мариенгофа оказала смена политических элит в 1920-е гг., эпатажный стиль и честность «Романа без вранья», а также публикация романа «Циники» в зарубежном издательстве, что выступило скорее формальной причиной. Причины же реальные для критики романа заключались в неоднозначности посыла самого произведения и в сложившемся образе Мариенгофа как отрицательного персонажа в мире советской литературы.

Реакция на «Роман без вранья» в «Злых заметках» Бухарина вылилась в дискуссию о том, каким должен быть советский писатель, и в кампанию против бывших имажинистов, именуемых «богемой». Скандал вокруг воспоминаний оказался определяющим для имиджа Мариенгофа в советской журналистике. Литературные критики в своих рецензиях придерживались тональности статьи Бухарина. Роман «Циники» не соответствовал идеальному образу советского литературного произведения, поэтому не был принят советской критикой. Вердикт роману в советской журналистике был вынесен одним заголовком «За Пильняком и Замятиным - Мариенгоф».

Мариенгоф не вышел сухим из воды и вынужден был завершить свою карьеру прозаика. Отношение к нему как к писателю на долгие годы вперед было сформировано полными негатива материалами, вышедшими в советских газетах и журналах в 1926-1929 гг.

\section{Список источников}

1. Адамович Г.В. 1929. Воспоминания о Есенине. Иллюстрированная Россия, 26 (215). 22 июня. Париж.

2. Айхенвальд Ю.И. 1927. Литературные заметки. Руль, 2005. 6 июля. Берлин: 2-3.

3. Айхенвальд Ю.И. 1928. Литературные заметки. Руль, 2430. 21 ноября. Берлин: 2-3.

4. Архангельский А.Г., Пустынин М.Я. 1927. Вранье без романа. На литературном посту, 20: $125-126$

5. [Б.п.]. 1929. Покаяние Мариенгофа. Воля России, 12: 134-135.

6. Бунин И.А. 1927. Самородки. Возрождение, 800. 11 августа. Париж: 12-19.

7. Бухарин Н.И. 1927. Злые заметки. Октябрь, 2: 131-137.

8. Воронский А.К. 1924. Литературные силуэты. Сергей Есенин. Красная новь, 1: 271-289.

9. Д.Н. 1929. За Пильняком и Замятиным - Мариенгоф. Красная вечерняя газета, 4. 19 октября. 
10. Демидов О.В. 2019. Анатолий Мариенгоф: первый денди Страны Советов: биография. Под ред. Е.Шубиной, М., Издательство АСТ, 749 с.

11. Катаев В.П. 1981. Алмазный мой венец. М., Советский писатель, 528 с.

12. Кут А. 1929. Почему писатели не едут в провинцию. Работа и искусство, 3. 4 декабря. 30 декабря.

13. Лавренев Б.А. 1925. Казненный дегенератами. Красная газета (веч. вып.), 315.

14. Ленин В.И. 1988. Письмо к съезду. В кн. Избранные произведения. М., Издательство политической литературы: 440-443.

15. Луначарский А.В. 1927. Вступительная статья. В кн. О писательской этике, литературном хулиганстве и богеме. Сб. статей под ред. А. Жарова. Л., Прибой: 3-13.

16. Мариенгоф А.Б. 1926. Воспоминания о Есенине. М., Огонёк, 55 с.

17. Мариенгоф А.Б. 1927. Роман без вранья. М., Прибой, 155 с.

18. Мариенгоф А. 1929. О романе А. Мариенгофа «Циники». Письмо А. Мариенгофа в правление Московского отдела Всероссийского Союза советских писателей от 1 ноября 1929 г. Литературная газета, 29. 4 ноября.

19. Мельникова-Папоушкова Н.Ф. 1929. Рецензия. Воля России, 1: 135-136.

20. О писательской этике, литературном хулиганстве и богеме. 1927. Сб. статей под ред. А. Жарова. Л., Прибой, 146 с.

21. Панов И. 1929. За большевизацию советской литературы (к политическим итогам пленума РАППа). Рост, 1: 86-87.

22. Постановление правления Московского отдела Всероссийского Союза советских писателей от 2 ноября 1929 г. 1929. Литературная газета, 29. 4 ноября.

23. Рецензия. 1926. Огонёк, 34 (178): 4.

24. Самсонов Т.П. 1929. «Роман без вранья» + «Зойкина квартира». Огонёк, 10 (310): 6-7.

25. Ходасевич В.Ф. 1927. Цыганская власть. Возрождение, 751. 23 июня: 3-4.

26. Шихман Б.С. 1927. «Голый» писатель. Гудок, 4. 15 июля.

\section{Список литературы}

1. Аверин Б.В. 2008. Скандальный успех. Анатолий Мариенгоф и Мишка Титичкин. В кн.: Семиотика скандала. Под ред. Норы Букс. М., Издательство «Европа»: 406-415.

2. Демидов О.В. 2012. А.Б. Никритина в жизни и творчестве А. Б. Мариенгофа. Вопросы русской литературы, 24 (81): 157-168.

3. Исаев Г.Г. 2015. Архетип эстета в дискурсах повествователя и лирического героя А. Мариенгофа 1920-х годов. Вестник РУДН. Серия: Литературоведение, журналистика, 1: 7-17.

4. Маквей Г. 2011. Поэт-имажинист Анатолий Мариенгоф: личность и творчество в зеркале современных исследований. Современное есениноведение, 16: 11-16.

5. Савченко Т.К. 2019. «Антимашинный лиризм»: Есенин и Арсений Несмелов. Русское слово в мультикультурном пространстве: сборник научных трудов к юбилею профессора Г.В. Якушевой. Под ред. М.А. Осадчий. Москва, Государственный институт русского языка им. А.С. Пушкина, 67-71.

6. Сухов В.А. 2012. Эволюция образа Москвы в творчестве А.Б. Мариенгофа. Известия ПГУ им. В.Г. Белинского, 27: 402-406.

7. Тернова Т.А. 2011. От имажинизма к советской литературе: тема русскости в произведениях А. Мариенгофа периода Великой Отечественной войны. Вестник ТГГПУ, 24: 229-233.

8. Фельдман Д.М. 2011. История «бакланки»: поэты, функционеры и советский уголовный кодекс. Новое литературное обозрение, 108: 116-133.

9. Фельдман Д.М. 2017. Литература и политика: российские писательские сообщества 1890-1920-х годов в политическом контексте. Россия и современный мир, 3 (96): 177-199.

10. Хуттунен Т. 2018. Имажинисты и кино: По поводу кинодраматургии А.Б. Мариенгофа. В кн. Серебряный век в русской литературе и культуре конца XIX - первой половины XX вв.: К 90-летию со дня рождения 3. Г. Минц. University of Tartu Press: 240-253.

11. Хуттунен Т. 2018. «Мариенгоф менее развратник, чем я думал»: Генри Парланд и русский имажинизм. Лебедь: Ежегодник финского литературоведения. Хельсинки. 2018. С. 35-53. 


\section{References}

1. Averin B.V. 2008. Skandal'nyy uspekh. Anatoliy Mariengof i Mishka Titichkin. [Scandalous success. Anatoly Marienhof and Mishka Titichkin.]. V kn.: Semiotika skandala. [Semiotics of scandal]. Ed. N. Buks. M., Publ. Evropa: 406-415.

2. Demidov O.V. 2012. A.B. Nikritina v zhizni i tvorchestve A.B. Mariengofa [A.B. Nikritina in the life and work of A.B. Marienhof]. Voprosy russkoy literatury, 24 (81): 157-168.

3. Isaev G.G. 2015. Arkhetip esteta v diskursakh povestvovatelya i liricheskogo geroya A. Mariengofa 1920-kh godov [The archetype of an esthete in the discourses of the narrator and lyric hero of A. Mariengof in the 1920s]. Vestnik RUDN. Literaturovedenie, zhurnalistika, 1: 7-17.

4. Makvey G. 2011. Poet-imazhinist Anatoliy Mariengof: lichnost' i tvorchestvo v zerkale sovremennykh issledovaniy [Imaginist poet Anatoly Marienhof: personality and creativity in the mirror of contemporary research]. Sovremennoe eseninovedenie, 16: 11-16.

5. Savchenko T.K. 2019. «Antimashinnyy lirizm»: Esenin i Arseniy Nesmelov [«Anti-machine lyricism»: Yesenin and Arseny Nesmelov]. In: Russkoe slovo v mul'tikul'turnom prostranstve: sb. nauchnykh trudov k yubileyu professora G.V. Yakushevoy [Russian word in a multicultural space: a collection of scientific papers for the anniversary of Professor G.V. Yakusheva]. Ed. M. A. Osadchy. Moscow, Pushkin State Institute of Russian language, 67-71.

6. Sukhov V.A. 2012. Evolyutsiya obraza Moskvy v tvorchestve A.B. Mariengofa [The evolution of Moscow image in the works of A.B. Marienhof]. Izvestiya PGU im. V.G. Belinskogo, 27: 402-406.

7. Ternova T.A. 2011. Ot imazhinizma k sovetskoy literature: tema russkosti v proizvedeniyakh A. Mariengofa perioda Velikoy Otechestvennoy voyny [From imaginism to Soviet literature: the theme of Russianness in the works of A. Marienhof during the Great Patriotic War]. Vestnik TGGPU, 24: 229-233.

8. Fel'dman D.M. 2011. Istoriya «baklanki»: poety, funktsionery i sovetskiy ugolovnyy kodeks [History of «baklanka»: poets, functionaries and the Soviet criminal code]. Novoe literaturnoe obozrenie, 108: $116-133$.

9. Fel'dman D.M. 2017. Literatura i politika: rossiyskie pisatel'skie soobshchestva 1890-1920-kh godov v politicheskom kontekste [Literature and politics: Russian writing communities of the 1890s1920s in a political context]. Rossiya i sovremennyy mir, 3 (96): 177-199.

10. Huttunen T. 2018. Imaginists and Film: On A.B. Mariengof's film scripts. In: The Silver Age in Russian Literature and Culture of the Late 19th - First Half of the 20th Centuries: On the 90th Anniversary of the Birth of Z. G. Mints University of Tartu Press, 240-253 (in Russian)

11. Huttunen T. 2018. «Mariengof is less pervers than I thought»: Henry Parland and Russian Imaginism. Joutsen: kotimaisen kirjallisuudentutkimuksen vuosikirja. Helsinki, 35-53 (in Russian)

\section{ИНФОРМАЦИЯ ОБ АВТОРЕ}

Муртазина Дарья Рашитовна, аспирант кафедры литературной критики Российского государственного гуманитарного университета, г. Москва, Россия

\section{INFORMATION ABOUT THE AUTHOR}

Daria R. Murtazina, Postgraduate student, Department of Literary Criticism, Russian State University for the Humanities, Moscow, Russia 